\title{
The Daily Activity Rhythm of Two Competitive Rodents: Clethrionomys glareolus and Apodemus flavicollis
}

\author{
Jan M. WOJCIK \& Krzysztof WOŁK
}

Wójcik J. M. \& Wołk K., 1985: The daily activity rhythm of two. competitive rodents: Clethrionomys glareolus and Apodemus flavicollis. Acta theriol., 30, 14: 241-258 [With 5 Tables \& 6 Figs.]

The CMR method was used to examine the activity of the bank vole Clethrionomys glareolus (Schreber, 1780) and the yellow-necked mouse Apodemus flavicollis (Melchior, 1834) in the Białowieża National Park during the period from 1967-1968. In spring C. glareolus was distinguished by a multi-phase daily activity pattern, with the main maximum during the morning hours. In 1967 there was a significant difference in the activity of males and females in the morning and at noon, although no differences were found the following spring. In summer C. glareolus was also distinguished by a daily activity rhythm with several peak periods. With considerable density of the individuals of both species (summer 1967) there was a distinct reduction in the activity of C. glareolus during the period when A. flavicollis was most active. This phenomenon was not observed during the remaining study periods. It was found in the summer of 1967 that adult males of C. glareolus exhibited more balanced activity over the 24-hour period than juvenile males, while females exhibited the opposite behaviour. With lower densities of rodents (summer of 1968) the activity pattern of C. glareolus, had three peaks of activity, with the main maximum at midnight, as was the case in spring. In autumn $C$. glareolus was active chiefly during the night hours $(18.00-04.00)$, only a few animals being caught during the day. No significant differences were found in the behaviour of males and females. A. flavicollis had a single-peak, typically nocturnal daily activity pattern in all seasons, with a maximum during the hours of 22.00-02.00. which did not exhibit any significant seasonal differences. It was only in the summer of 1967 that adult males were more active at night than juvenile males, while the reverse relation was found during the daytime.

[Mammals Res. Inst., Polish Acad. Sci.. 17-230 Białowieża; and Forest Res. Inst., Sect. Nat. Protection, 17-230 Białowieża, Polandl

\section{INTRODUCTION}

The daily activity rhythms of small rodents and insectivores are among those mammalian rhythms which have been most thoroughly investigated. Some of these studies, however, were carried out under artificial laboratory conditions (e.g. Kowalski, 1951; Miller, 1955; Durup \& Saint Girons, 1958; Grodziński, 1962; Górecki, 1968), making care necessary when relating results to the behaviour of animals in a natural habitat. In order to interpret the effect of different habitat factors, intrapopulation relations and inter-action between species on the activity of small mammals field studies, which are more difficult to carry out, were 
undertaken. It was shown that the daily activity rhythms of animals vary according to season and are greatly affected by periodical changes in physical habitat conditions (Brown, 1956; Ostermann, 1956, Saint Girons, 1960, 1961; Erkinaro, 1961; Vickery \& Bider, 1981), food supply (Grodziński, 1963; Kuznetsov, 1968; Greenwood, 1978), numbers and social relations (Saint Girons, 1960; Kikkawa, 1964; Sokolov \& Kuznetsov, 1978). Attention was also paid to interactions between species (Brown, 1956; Andrzejewski \& Olszewski, 1963; Buchalczyk, 1964; Greenwood 1878) and the influence of predators on the activity of small rodents (Sokolov \& Kuznetsov, 1978).

In the present study a description is given of seasonal changes and sex and age differences in the daily activity of the bank vole Clethrionomys glareolus (Schreber, 1780) and yellow-necked mouse Apodemus flavicollis (Melchior, 1834). The question of interactions between species on daily rhythm, depending on differing densities of these commonly co-occurring rodents, has also been considered.

\section{HABITAT DESCRIPTION}

The study area was situated in sector $370 \mathrm{C}$ of the Białowieża National Park (Fig. 1), in one of the largest Tilio-Carpinetum stands. It is a natural stand of old trees composed of many layers and different ages, with a complicated structure.

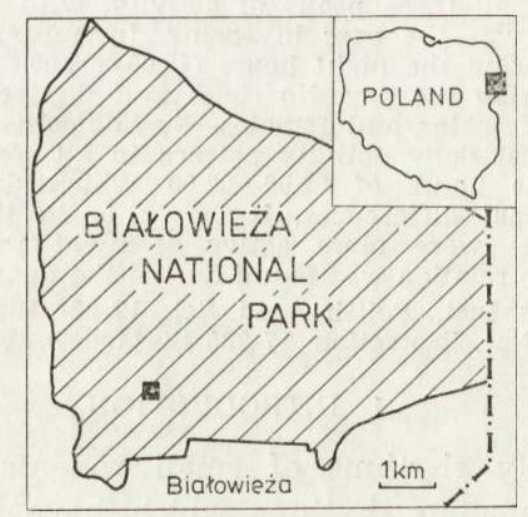

Fig. 1. Localization of study area. Black square - trapping area, continuous line - boundary of the Białowieża National Park, dotted line - state boundary.

The upper layer of trees is formed by oaks, limes, spruces, maples and ashtrees, and the lower layers by hornbeam. The undergrowth occurs below the tree layer and connects without interruption with the bush layer. There are gaps in the treestand caused by old trees falling, and there nettles and wild raspberry bushes grow. The herb layer is typical of the natural dry tree stands of the Bialowieża Primeval Forest. The following species occur numerously: Allium ursinum L., 
Stachys silvatica L., Hepatica nobilis Garsault, Dentaria bulbifera L. and others. In order to illustrate the habitat situations in the study area a schematic description has been given of the dry forest phenology during the study period (Fig. 2).

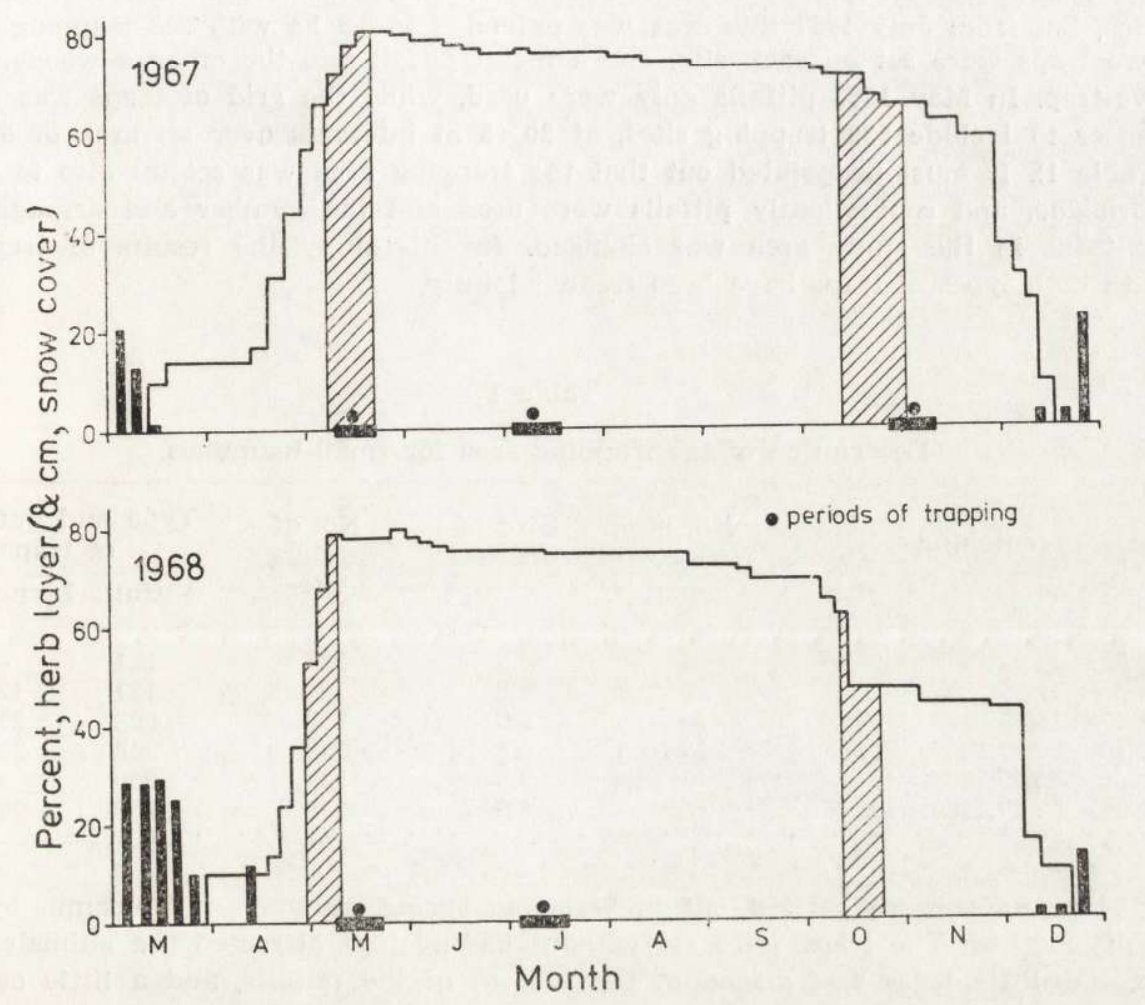

Fig. 2. Periods of trapping small mammals in relation to the phenology of the Tilio-Carpinetum association: depth of snow cover (columns), periods of density of leaves and falling of leaves (diagonal shading) and percentage of herb layer cover (continuous line). Data of the phenogram from an analogical habitat (after J. B. Faliński, unpubl.).

There were numerous trunks of uprooted trees in different stages of decomposition in the study area, and under these trunks there were a large number of places sheltered from atmospheric precipitation. From time to time the patches of herb layer were rooted up by wild boar.

The study area was approx. $1200 \mathrm{~m}$ from the edge of the forest. On the north there was a similar dry tree stand, but towards the east this stand gradually changed to the wetter from of this association, while from the South there was a narrow belt of the Circaeo-Alnetum association. 


\section{MATERIAL AND METHODS}

The study area was laid out in the place chosen by field consulation with a phytosociological expert (Dr. A. W. Sokolowski), endeaviouring to locate a relatively homogeneous patch of plant association. A regular grid of traps was set up on the site with $20 \mathrm{~m}$ intervals between traps. During the first trapping series (May 1967) captures were made over an area of $4.8 \mathrm{ha}$, with 121 trapping sites, but from July 1967 this area was extended to 8.3 ha with 208 trapping sites. Two traps were set on each site, one a metal pitfall and the other a wooden box live-trap. In May 1968 pitfalls only were used, while the grid of traps was made denser to include 539 trapping sites, at $20 \times 5 \mathrm{~m}$ intervals over an area of $8.3 \mathrm{ha}$ (Table 1). It must be pointed out that the trapping area was set up also to catch Soricidae, and consequently pitfalls were used and the number and arrangement of traps in the study area was changed. In this study the results of trapping with both types of traps have been treated jointly.

Table 1

Description of the trapping area for small mammals.

\begin{tabular}{lccccc}
\hline Date of catching & $\begin{array}{c}\text { No. of } \\
\text { days }\end{array}$ & $\begin{array}{c}\text { Size of } \\
\text { area,ha }\end{array}$ & $\begin{array}{c}\text { No. of } \\
\text { catching } \\
\text { sites }\end{array}$ & $\begin{array}{c}\text { Type and number } \\
\text { of traps }\end{array}$ \\
\hline Pitfalls Live-traps \\
11.05.-11.05.1967
\end{tabular}

The studies were carried out in series in spring, summer and autumn by the CMR method. The traps were set without having first attracted the animals with bait. A little moss was placed at the bottom of the pitfalls, and a little oats in the live-traps. The traps were inspected every two hours. The round of inspection of the traps began punctually at an even-number hour and always along the same route. From 2-5 persons looked after the trapping area. The following were entered on trapping cards: hour of capture, site number, species of animal, its individual number, sex and age. In the case of males information was entered as to the state of the gonads (sexually active or inactive) and in the case of females information as to gestation and lactation. The animals' age was estimated in two categories: young (juv.) and adult (ad.) on the basis of external characteristics.

During the course of five series of trappings the total numbers marked were 1205 individuals of Clethrionomys glareolus (hereinafter C.g.), which were caught 5188 times, and 900 individuals of Apodemus flavicollis (hereinafter A.f.), which were caught 3323 times (Table 2). The results of captures of adult and juvenile animals of C.g. and A.f. in summer series (July 1967 and 1968) are given in Table 3.

The numbers of marked individuals of C.g. and A.f. differed both in seasons and in years. The number of marked individuals during the first five days of trapping, that is, during 60 inspections of traps, converted to 1 ha $\left(\left(\mathrm{N}_{1-s \mathrm{ds}} / \mathrm{ha}\right)\right.$ 
Table 2

Comparison of trapped males and females of Clethrionomys glareolus and Apodemus flavicollis during different trapping periods.

$\mathrm{a}$ - number of catches, $\mathrm{b}$ - number of marked individuals.

\begin{tabular}{|c|c|c|c|c|c|c|c|c|c|c|c|c|}
\hline \multirow{3}{*}{$\begin{array}{l}\text { Year. } \\
\text { season }\end{array}$} & \multicolumn{6}{|c|}{ C. glareolus } & \multicolumn{6}{|c|}{ A. flavicollis } \\
\hline & \multicolumn{2}{|c|}{ Males } & \multicolumn{2}{|c|}{ Females } & \multicolumn{2}{|c|}{ Total } & \multicolumn{2}{|c|}{ Males } & \multicolumn{2}{|c|}{ Females } & \multicolumn{2}{|c|}{ Total } \\
\hline & a & b & a & b & a & b & a & b & a & b & a & b \\
\hline \multicolumn{13}{|l|}{1967} \\
\hline Spring & 99 & 34 & 85 & 27 & 187 & 61 & 143 & 51 & 108 & 38 & 251 & 89 \\
\hline Summer & 2022 & 252 & 1711 & 221 & 3733 & 473 & 1051 & 121 & 891 & 143 & 1942 & 264 \\
\hline Autumn & 61 & 46 & 116 & 61 & 177 & 107 & 399 & 160 & 438 & 162 & 837 & 322 \\
\hline 1968 & & & & & & & & & & & & \\
\hline Spring & 163 & 97 & 126 & 76 & 289 & 173 & 20 & 16 & 23 & 18 & 43 & 34 \\
\hline Summer & 347 & 179 & 458 & 212 & 805 & 391 & 143 & 104 & 107 & 87 & 250 & 191 \\
\hline Total & 2692 & 608 & 2496 & 597 & 5188 & 1205 & 1756 & 452 & 1567 & 448 & 3323 & 900 \\
\hline
\end{tabular}

Table 3

Comparison of adult and juvenile males and females of Clethrionomys glareolus and Apodemus flavicollis caught during the summer season of 1967 and 1968 . Symbols as for Table 2 .

\begin{tabular}{|c|c|c|c|c|c|c|c|c|c|c|c|c|}
\hline \multirow{3}{*}{$\begin{array}{l}\text { Year, } \\
\text { Age }\end{array}$} & \multicolumn{6}{|c|}{ C. glareolus } & \multicolumn{6}{|c|}{ A. flavicollis } \\
\hline & \multicolumn{2}{|c|}{ Males } & \multicolumn{2}{|c|}{ Females } & \multicolumn{2}{|c|}{ Total } & \multicolumn{2}{|c|}{ Males } & \multicolumn{2}{|c|}{ Females } & \multicolumn{2}{|c|}{ Total } \\
\hline & a & b & a & b & a & b & 2 & b & a & b & a & b \\
\hline \multicolumn{13}{|l|}{1967} \\
\hline Ad & 1173 & 92 & 1133 & 86 & 2306 & 178 & 820 & 86 & 368 & 47 & 1188 & \\
\hline Juv & 84 & 160 & 578 & 135 & 1427 & 295 & 23 & 35 & 523 & 96 & 754 & 131 \\
\hline Ad. & 187 & 88 & 243 & 80 & $43 c$ & 168 & 103 & 69 & 59 & 46 & 162 & 115 \\
\hline Juv. & 160 & 91 & 215 & 132 & 375 & 223 & 40 & 35 & 48 & 41 & 88 & 2 \\
\hline Total & 2369 & 431 & 2169 & 433 & 4538 & 864 & 1194 & 225 & 998 & 230 & 2192 & 455 \\
\hline
\end{tabular}

Table 4

Indices of relative density of Clethrionomys glareolus and Apodemus flavicollis per 1 ha of trapping area expressed by the number of animals caught during the first 5 days of trapping.

\begin{tabular}{lcc}
\hline \multirow{2}{*}{$\begin{array}{l}\text { Year, } \\
\text { Season }\end{array}$} & Relative density $\left(\mathrm{N}_{1-5 \mathrm{ds}} / \mathrm{ha}\right)$ \\
\cline { 2 - 3 } & C. glareolus & A. flavicollis \\
\hline 1967 & & \\
Spring & 7.5 & 9.4 \\
Summer & 39.3 & 20.0 \\
Autumn & 4.7 & 22.3 \\
1968 & & \\
Spring & 15.7 & 3.1 \\
Summer & 24.7 & 16.0 \\
\hline
\end{tabular}


(Table 4) was taken as a relative measure of density. The decided majority (over $75 \%$ ) of individuals of both species were caught within five days in each trapping series. If we assume that individuals with two or more captures were resident animals, we obtain results very similar to those calculated by the above method. It would be very difficult to use any other method with this way of obtaining data.

The data collected were analyzed in this paper from the aspect of the daily activity of C.g. and A.f., taking the frequency of captures of the animals at a given hour of the day as a measure of their activity. Differences in the activity pattern of both species in successive years, seasons and depending on sex were also analyzed. The activity of adult individuals participating in reproduction (sexually active males and pregnant and lactating females) and juvenile animals not taking part in reproduction were analyzed separately in the case of material from summer periods (July 1967 and 1968). The chi-square test was used in order to grasp the statistically significant differences in the number of captures of two groups of individuals in a given trapping hour.

\section{RESULTS}

\subsection{General Daily Activity Patterns}

In spring C.g. is characterized by a multi-phase daily activity rhythm with one distinct peak at 08.00 and a smaller peak at midnight (Fig. 3A and B). A.f. is distinguished by a single-phase activity rhythm with a maximum at midnight (1967) or at 02.00 (1968) (Fig. 3A and B).

In the summer of 1967 , when there was considerable frequency of

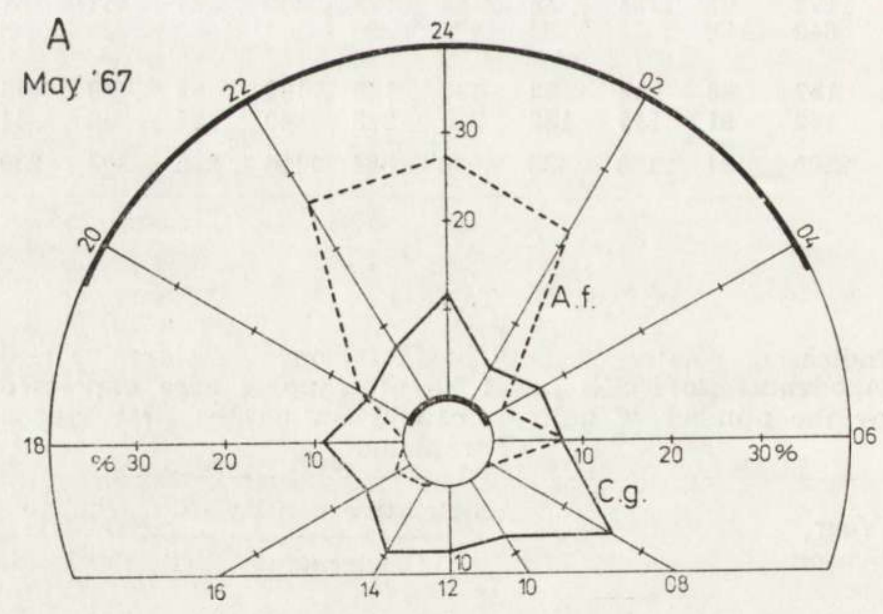

Fig. 3A-E. Daily activity rhythms of Clethrionomys glareolus and Apodemus flavicollis in different trapping periods. Polygons show the distribution in percentages of captures at different times of the day. Thick line - night, thin line - day. 

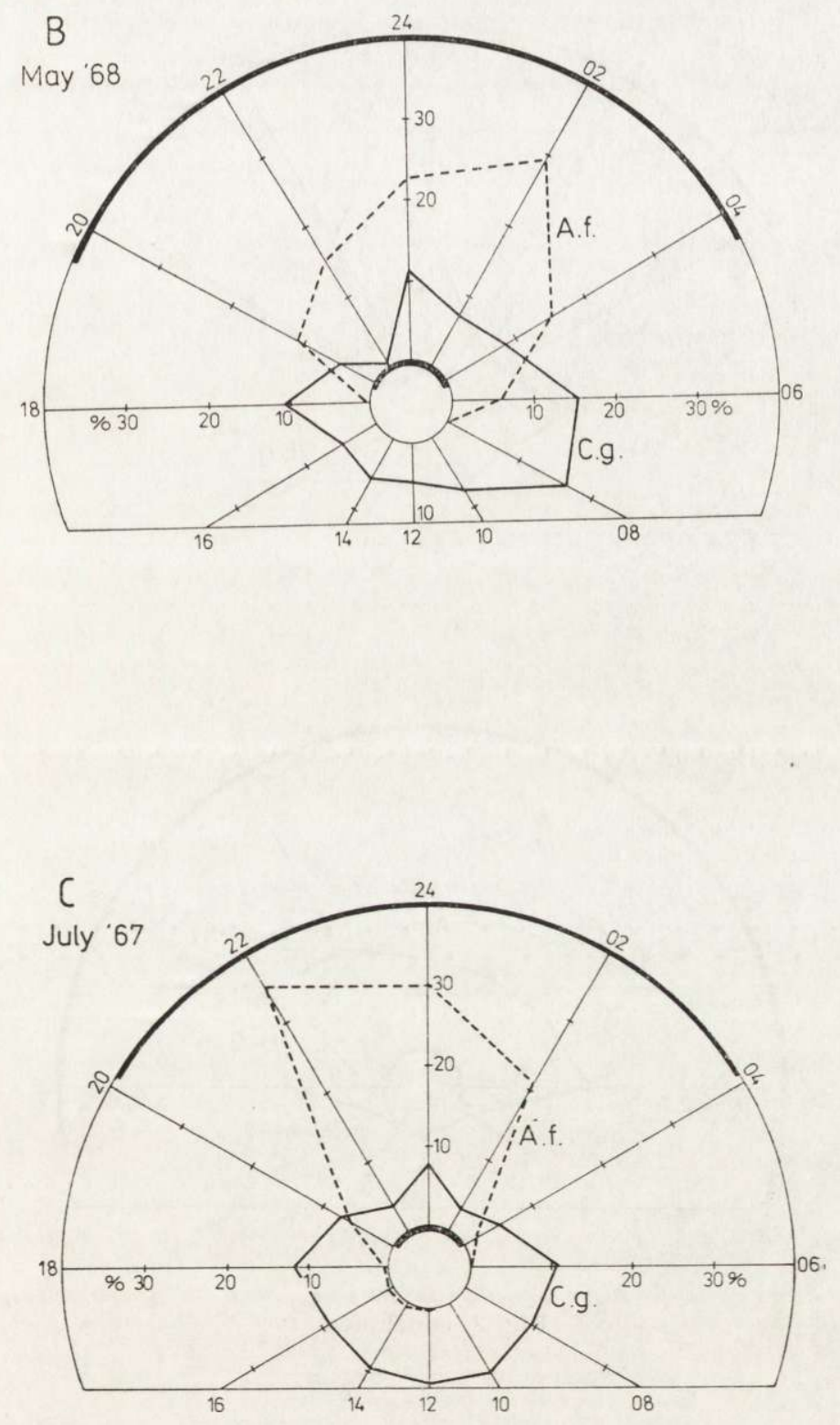

Fig. 3, continued. 

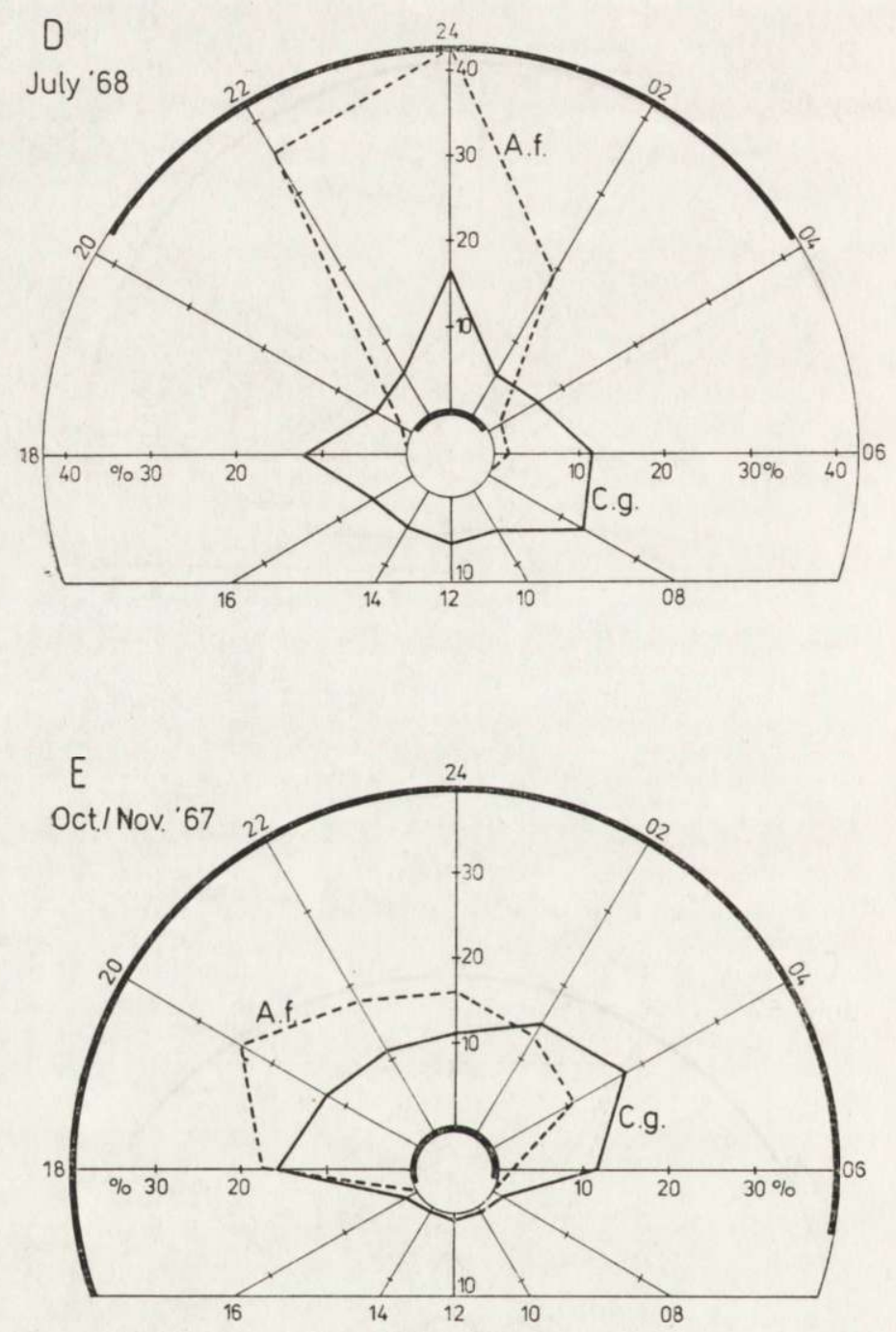

Fig. 3, concluded.

captures of representatives of the two species, C.g. was distinguished by a very balanced daily activity and distinct nocturnal reduction in activity from $20.00-04.00$, but exhibited increased activity at midnight (Fig. 3C). The daily activity rhythm of C.g. in the summer of 1968, with far lower frequency of capture of representatives of both species, was similar to spring rhythms and was characterized by three distinct peaks 
at $08.00,18.00$ and 24.00 (Fig. 3D). In both summer periods A.f. had a single-phase typically nocturnal activity rhythm. After dusk there was an abrupt increase in frequency of captures which reached a peak between $22.00-24.00$, after which an equally sudden decrease up to dawn was observed. A.f. practically inactive during the day (Fig. 3C and D).

In autumn, unlike preceding seasons, C.g. was active chiefly during the night hours. The activity rhythm did not exhibit any distinct multi-phase character - nocturnal activity was maintained on a high level in the interval from $12-18 \%$ of captures, but during the day only a few: representatives of C.g. were caught (Fig. 3E). The activity rhythm of A.f., on the other hand, differed very little in comparison with other periods. In this case also almost $100 \%$ of captures took place during the night hours, with a maximum at 20.00 (Fig. 3E).

\subsection{Differences in Daily Activity Rhythm}

4.2.1. Activity in Successive Years

Successive study years differed in respect of weather and phenology (Fig. 2), and in respect of the density of individuals of both species in the study area (Table 3 ). A check was made to determine whether the daily activity rhythm of C.g. and A.f. differed in successive years.

The daily activity rhythm of C.g. in May 1967 has one significant peak of activity at 08.00 , but the remaining values do not differ significantly from the homogeneous distribution. The activity rhythm of C.g. in May of the following years is not so homogeneous, since it has three significant maxima at $06.00-08.00,18.00$ and 24.00 and one significant minimum at 22.00. The spring distributions of captures of C.g. differ significantly at 06.00 and 22.00 (Fig. 4).

In May 1967 A.f. was active chiefly from $22.00-02.00$, when a joint total of $78 \%$ of captures of representatives of this species were recorded. Apart from this a small percentage of A.f. was captured at $06.00,16.00$ and 22.00 . During the subsequent spring the peak activity of A.f. occurred at $24.00-02.00$. In addition at 04.00 and $20.00-22.00$ A.f. exhibited considerable activity in the trapping interval of $12-15 \%$, whereas none were caught from 08.00-18.00. The spring distributions of captures for A.f. differ significantly at 04.00 (Fig. 4).

Distinct differences in the activity of C.g. could be observed during the summer seasons. The daily activity rhythm of C.g. in July 1967 has two significant minima from $02.00-04.00$ and 22.00 , but did not differ significantly from the homogeneous distribution during the remaining 
hours of the day. A clearly different daily activity rhythm was obtained for July of the following year for C.g., since at $06.00-08.00$ and 24.00 it differed significantly from the homogeneous distribution. The summer distributions of captures for C.g. differ significantly in the interval of hours $08.00-16.00$ and $20.00-24.00$ (Fig. 4).

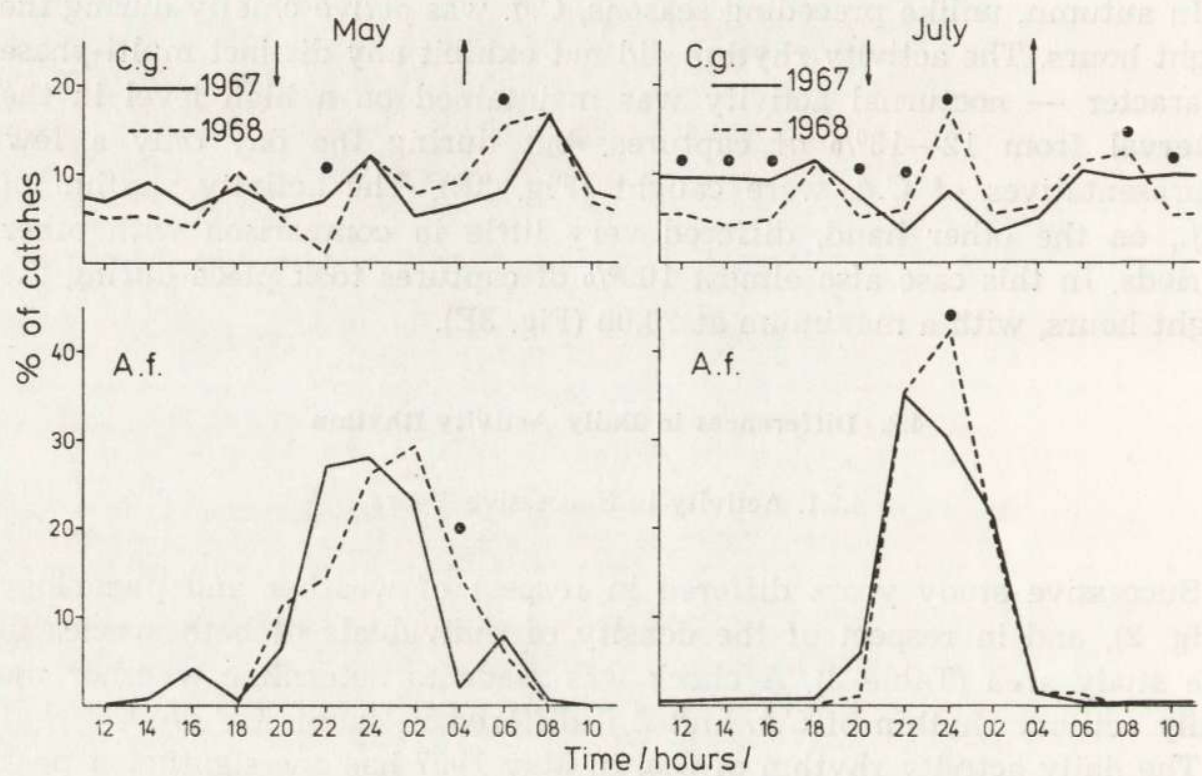

Fig. 4. Comparison of distributions in percentages of captures of Clethrionomys glareolus and Apodemus flavicollis from two spring and summer trapping series. Arrows indicate sunrise and sunset. Dots indicate statistically significant differences $(\mathrm{df}=1, p=0.05)$.

The daily distributions of captures for A.f. in July 1967 and 1968, unlike those for C.g., differed very little. There was a significant difference only at 24.00 , due to the fact that the maximum activity of A.f. in July 1967 occurred at 22.00 , and in the following year at 24.00 (Fig. 4).

\subsubsection{Activity of Males and Females}

The activity rhythm of C.g. and A.f. males and females in different seasons exhibit only slight differences. In the case of C.g. statistically significant differences occurred in May 1967 at $08.00,12.00$ and 16.00, and in July 1968 at 02.00 and 16.00 . In both cases greater jumps in the trapping curve were found for C.g. females, whereas no significant differences were found in the activity of male and female C.g. in the other periods (Fig. 5A, B and C). 
Male and female A.f. exhibited even greater agreement in their daily activity rhythms than those of C.g. Differences were found only in May 1968 , when two peaks occurred, non-typical of A.f., in their daily activity rhythm (Fig. 5A, B and C).
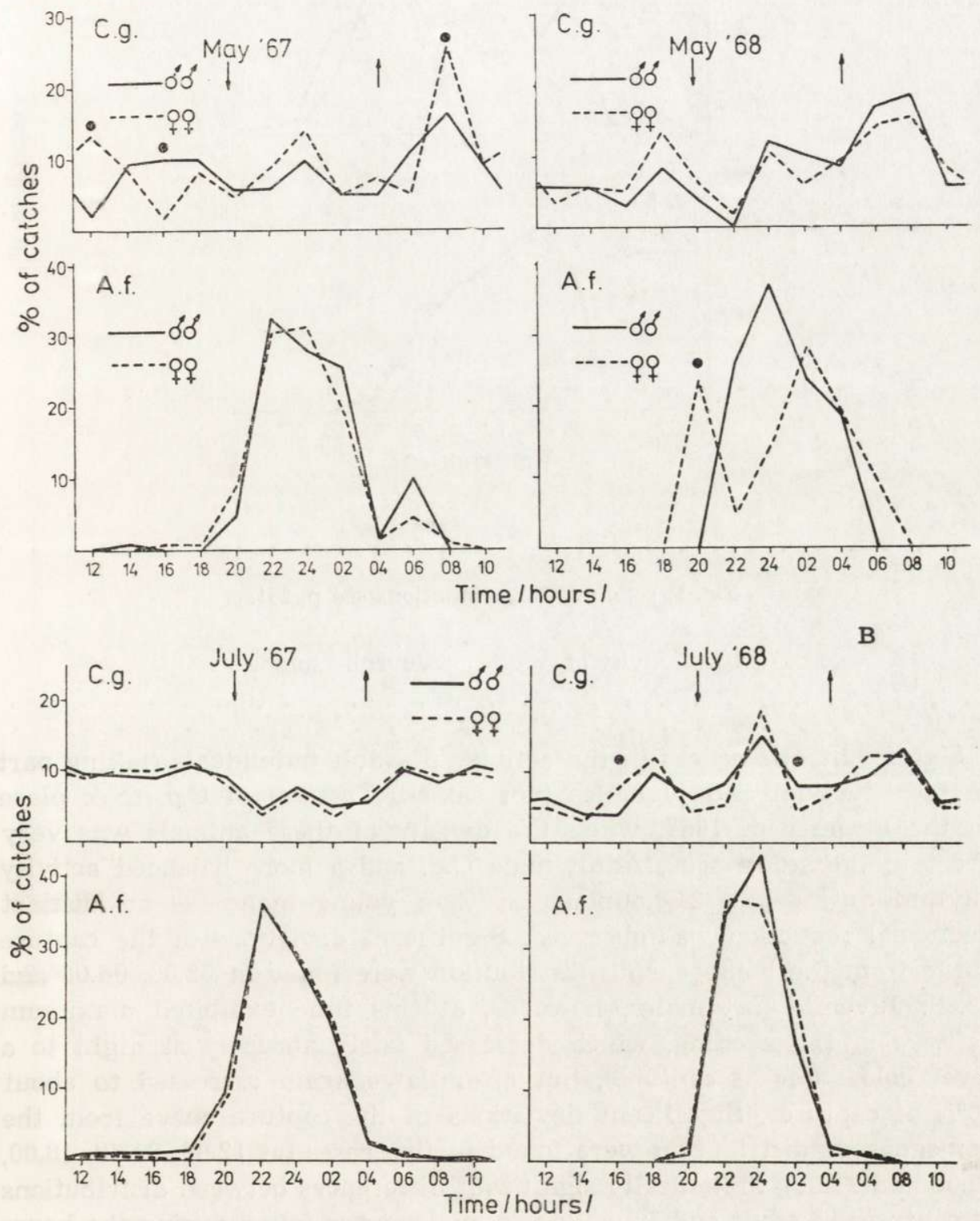

Fig. 5A-C. Comparison of distributions in percentages of the captures of males and females of Clethrionomys glareolus and Apodemus flavicollis in different trapping periods. Symbols as for Fig. 4. 


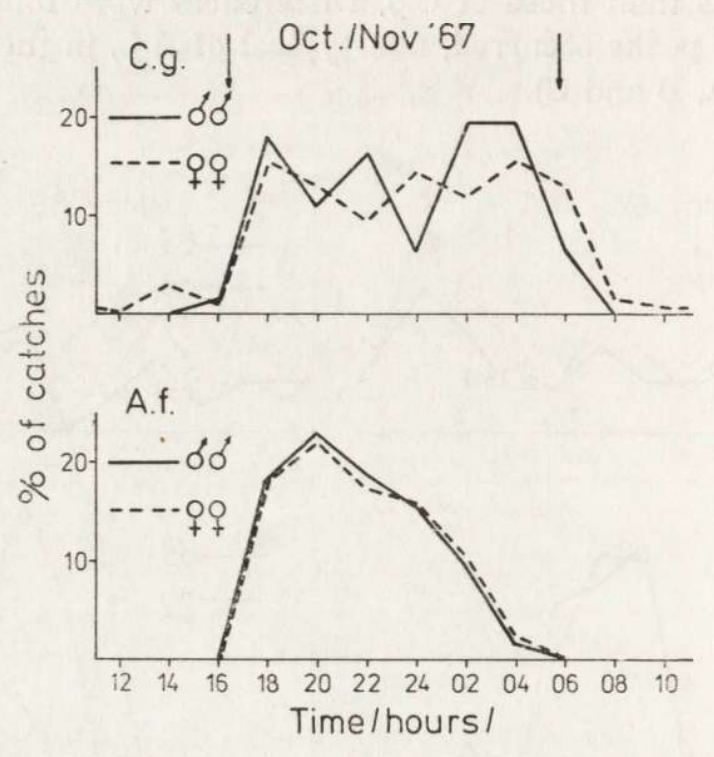

Fig. 5, concluded. Explanations see p. 251.

4.2.3. Activity of Adult and Juvenile Animals

Significant differences in the activity of adult individuals (taking part in reproduction) and juveniles (not sexually active) of C.g. took place in the summer of 1967, when the density of these animals was very great in the study area. Adult male C.g. had a more balanced activity rhythm during the 24-hour period than young males - no distinct nocturnal reduction was observed. Significant deviations of the capture curve from the homogeneous distribution were found at $02.00,06.00$ and 22.00. Juvenile C.g. males, however, at this time exhibited maximum activity in the evening, which decreased fairly abruptly at night to a level below $5 \%$ of captures, but after dawn again increased to about $10 \%$ of captures. Significant deviations of the capture curve from the homogeneous distribution were found in five cases (at 12.00, 04.00, 18.00, 22.00 and 24.00). Statistically significant differences between distributions of captures of adult and juvenile C.g. males were found during the hours of $16.00-18.00$ and $24.00-04.00$ (Fig. $6 \mathrm{~A}$ ).

The daily activity rhythm of adult C.g. females in the summer of 1967 was characterized by two fairly distinct peaks in the morning and 
evening and distinct nocturnal decrease. Significant deviations of the trapping curve from the homogeneous distribution occurred at 02.00 , $06.00,18.00$ and 22.00 . Unlike adult females, the juvenile females were
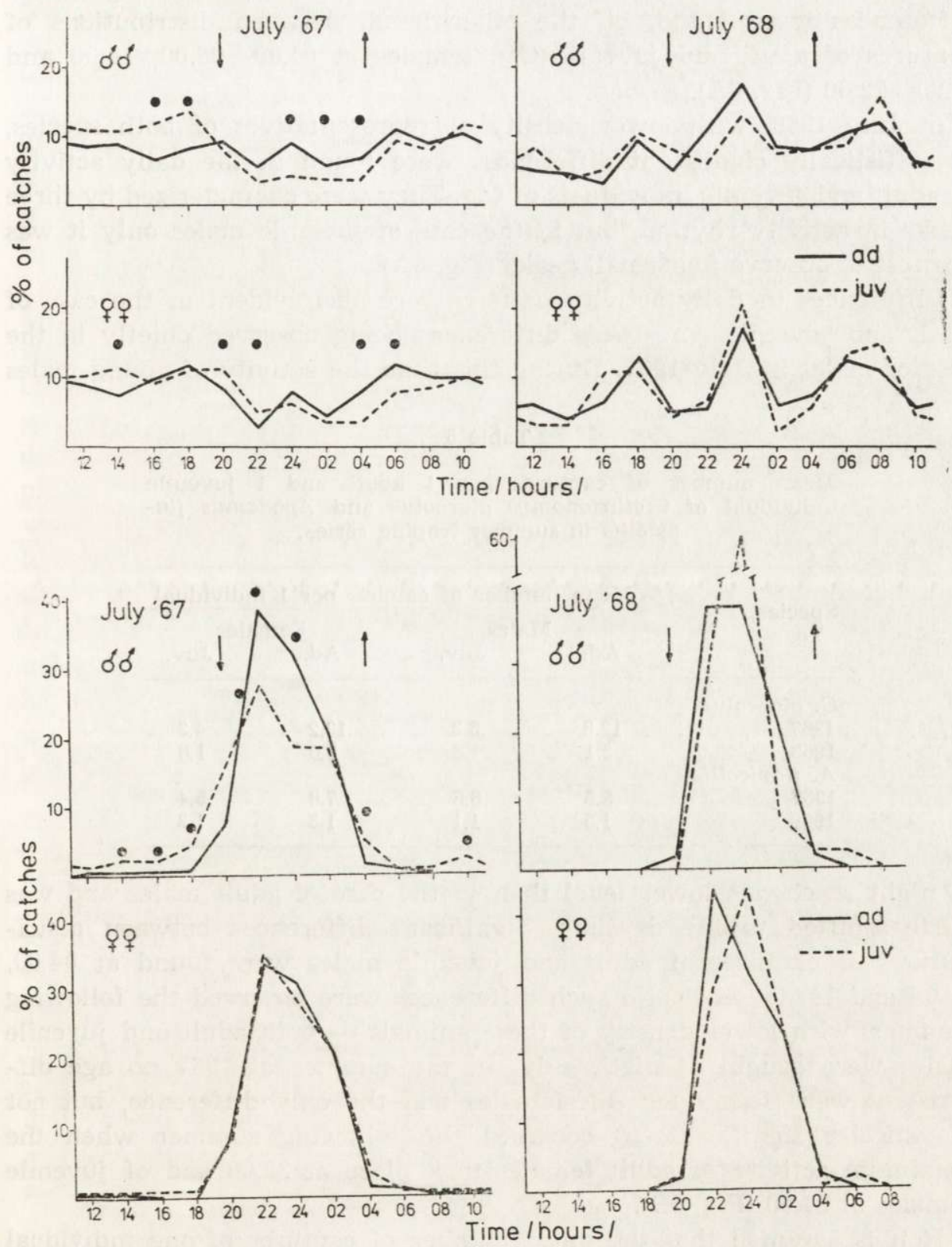

Fig. 6A-B. Comparison of distributions in percentages of the captures of adult and juvenile individuals of Clethrionomys glareolus and Apodemus flavicollis in two summer trapping series. Symbols as for Fig. 4. 
active for a longer time in the evening, and after dawn slowly reached peak activity. Significant deviations in the trapping curve from the homogeneous distribution occurred at $02.00,04.00$ and 22.00. Significant differences were found, on the other hand, between distributions of captures of adult and juvenile C.g. females at $04.00-06.00,14.00$ and $20.00-22.00$ (Fig. 6A).

In July 1968, with lower density of representatives of both species, no statistically cignificant differences were found in the daily activity of adult and juvenile individuals of $(. g$. They were characterized by three peaks in activity rhythm, but in the case of juvenile males only it was possible to observe four small peaks (Fig. 6A).

Differences in daily activity pattern were also evident in the case of adult and juvenile A.f., these differences being observed chiefly in the case of males in July 1967. During this time the activity of young males

Table 5

\begin{tabular}{|c|c|c|c|c|}
\hline \multirow{3}{*}{$\begin{array}{l}\text { Species, } \\
\text { Year }\end{array}$} & \multicolumn{4}{|c|}{ Mean number of catches per 1 individual } \\
\hline & \multicolumn{2}{|c|}{ Males } & \multicolumn{2}{|c|}{ Females } \\
\hline & Ad. & Juv. & Ad. & Juv. \\
\hline \multicolumn{5}{|l|}{ C. glareolus } \\
\hline 1967 & 12.8 & 5.3 & 13.2 & 4.3 \\
\hline $\begin{array}{l}1968 \\
\text { A. flavicollis }\end{array}$ & 2.1 & 1.8 & 3.0 & 1.6 \\
\hline A. flavicollis & 8.5 & 6.6 & 7.8 & 5.4 \\
\hline 1968 & 1.5 & 1.1 & 1.3 & 1.2 \\
\hline
\end{tabular}

at night reached a lower level than in the case of adult males and was partly shifted to the daytime. Significant differences between distributions of captures of adult and juvenile males were found at 04.00 , 10.00 and $14.00-24.00$. No such differences were observed the following summer, with lower density of these animals - both adult and juvenile males were caught at nigth only. In the summer of 1967 no age differences were found for A.f. females and the only difference, but not statistically significant, to occurred the following summer when the maximum activity of adult females took place at 22.00 and of juvenile females at 24.00 (Fig. $6 \mathrm{~B}$ ).

If it is assumed that the mean number of captures of one individual also form a measure of its activity, it will be found that in both summer study periods adult individuals of C.g. and A.f. were more active (were caught a greater number of times) than juvenile animals (Table 5). 


\section{DISCUSSION}

Despite the fact that repeat series of trappings were carried out in spring and summer 1967 and 1968 at the same calendar periods, different results were obtained, the situations of the study populations being different - different density and different habitat situation. The traps were inspected with maximum frequency possible under the given conditions and it may be concluded that the picture of daily activity obtained is a true picture of the real situation. On the other hand the fact of the animals being conditioned to the bait used might have disturbed their natural activity rhythm.

The data presented prove that C.g. is distinguished by a more plastic daily activity rhythm, unlike A.f., for which species it is very stable with one peak, and nocturnal. This is due inter alia to ethological differences which decide upon the way in which these species make use of space. Sokolov \& Kuznetsov (1978) state that C.g. and A.f. behave very diferently when released into a limited area. C.g. at once finds a hidingplace and takes shelter there, while before doing so A.f. runs along the wall for several minutes ( $3-5$ min.). Under natural conditions C.g. has several temporary burrows which enable it to escape rapidly from danger during the daytime or at night. A.f., distinguished by long wanderings and great rapidity of movement $(58.6 \mathrm{~m} / \mathrm{min})$ (Tumanov, 1969), moves over a considerable area within a short time, chiefly at night, and has no temporary burrows. These kinds of behaviour favour the formation in C.g. of a day-night daily activity rhythm with a large number of phases, but a single-phase nocturnal rhythm in A.f.

The character of daily activity rhythms in the species examined is successive seasons and years may be conditnoned, inter alia, by the kind of food and the abundance of the food supply in the forest. The lack of variability in the activity pattern of $A$.f. over the course of a year may be explained by the fact that they feed chiefly on high-calorie food (nuts, berries and insects) (Górecki \& Gębczyńska, 1962; Obrtel \& Holišova, 1974). This kind of food and a high degree of activity favour the formation of a single-phase activity rhythm. On the other hand the less active C.g., which consumes more of the green parts of plants (Górecki \& Gębczyńska, 1962; Obrtel \& Holišova, 1974) must have a multi-phase and varying daily activity rhythm to fit the seasonally changing food supply. Proofs of this have been described earlier by other authors (Grodziński, 1962, 1963; Kuznetsov, 1968; Sokolov \& Kuznetsov, 1978).

The animals' activity clearly depends on population density. When there is great density during the reproduction period, during which the number of contacts between individuals in a given population increase 
considerably, differences can be observed in the activity of adult and juvenile animals. Such differences are clearest in the case of C.g. males in the summer of 1967. Adult males had more balanced activity over the course of 24 hours than juvenile males, which were clearly less active at night than during the day. An effect of this type, but less clearly evident, can be seen in the case of A.f. males also. The following year, when there was lesser density of populations, no such differences were found, which shows that population density plays an important part in this case. In many earlier studies it was also found that the general activity of rodents changes according to season and obviously depends on population density (Saint Girons, 1960, Andrzejewski \& Wierzbowska, 1961; Kulicke, 1862; Kikkawa, 1964; Mazurkiewicz, 1983).

When there is great density of individuals belonging to competitive species in the same habit, their activity rhythms diverge during the 24hour period. This effect was evident during the period of maximum density and during the time of the greatest activity of A.f. At this time the activity of C.g. was observed to decrease significantly, caused by the intensified penetration of the area by A.f. When, however, A.f. was caught in smaller numbers, no such distinct effect was observed. The studies by Andrzejewski \& Olszewski (1963) showed that encounters between individuals of A.f. and C.g. are usually those of aggressive and attacking mice. In addition several other authors have shown that the nocturnal inhibition of activity in C.g. is due to the effect of aggressive and numerous A.f., which exhibit maximum activity during the night hours (Naumov, 1948; Brown, 1956; Buchalczyk, 1964; Greenwood, 1978). When, however, the effect of A.f. is limited, then C.g. is characterized by fairly great nocturnal activity. Such results were obtained in autumn and in summer (1968), when few A.f. were caught and most probably only slightly affected the activity of C.g. Similar daily activity rhythms were observed under both laboratory and field conditions (Ostermann, 1956; Saint Girons, 1960, 1961; Górecki, 1968; Petrusewicz, Górecki, Grodziński \& Kozłowski, 1983). It would appear that this is the natural, evolutionally determined daily activity rhythm of C.g.

The facts presented in this paper confirm the opinion that activity patterns imprinted by evolution and ecologically valid (see Ashby, 1872; Kavanau \& Havenhill, 1976) must be characterized by some degree of plasticity, permitting populations of small rodents to make better use of the ecological niches they occupy.

Acknowledgements: Our sincere thanks are due to the following for their untiring work in the servicing of the trapping area: W. Bajko, T. Borowska, S. Buszko, Z. Karunos, A. Krasowska, A. Laszkiewicz, J. Lipińska, E. Piątkowska, J. Ruprecht, L. Siemieniuk and E. Wolk. 


\section{REFERENCES}

1. Andrzejewski R. \& Olszewski J. L., 1963: Social behaviour and interspecific relations in Apodemus flavicollis (Melchior, 1834) and Clethrionomys glareolus (Schreber, 1780). Acta theriol., 7: 155-168.

2. Andrzejewski R. \& Wierzbowska T., 1961: An attempt at assessing the duration of residence of small rodents in defined forest area and the rate of interchange between individuals. Acta theriol., 5: 153-172.

3. Ashby K. R., 1972: Paterns of daily activity in mammals. Mammal Rev., 1: $171-185$.

4. Brown L. E., 1956: Field experiments an the activity of the small mammals Apodemus, Clethrionomys and Microtus. Proc. zool. Soc., London, 126: 549-564.

5. Buchalczyk T., 1964: Daily activity rhythm in rodents under natural conditions. Acta theriol., 9: 357-362.

6. Durup H. \& Saint Girons M. Ch., 1958: Quelques aspects du rythme nycthéméral d'activité du Campagnol roux, Clethrionomys glareolus (Schreber) 1780. Mammalia, 22: 505-526.

7. Erkinaro E., 1961: The seasonal change of the activity of Microtus agrestis: Oikos, 12: 157-163.

8. Górecki A. \& Gębczyńska Z., 1962: Food conditions for small rodents in a deciduous forest. Acta theriol., 6: 275-295.

9. Gorrecki A., 1968: Metabolic rate and energy budget in the bank vole. Acta theriol., 13: $341-365$.

10. Greenwood P. J., 1978: Timing of activity of the bank vole Clethrionomys glareolus and the wood mouse Apodemus sylvaticus in a deciduous woodland. Oikos, 31: 123-127.

11. Grodziński W., 1962: Influence of food upon the diurnal activity of small rodents. Symp. theriol., Czechosl. Acad. Sci.: 134-140. Praha.

12. Grodziński W., 1963: Sezonowe zmiany w rytmice dobowej aktywności drobnych gryzoni. Ekol. pol. B, 9: 3-17.

13. Kavanau J. L. \& Havenhill R. M., 1976: Compulsory regime and control of environment in animal behaviour III. Light level preferences of small nocturnal? mammals. Behaviour, 49: 203-225.

14. Kikkawa J., 1964: Movement, activity and distribution of the small rodents Clethrionomys glareolus and Apodemus sylvaticus in woodland J. Anim. Ecol., 33: 259-299.

15. Kowalski K., 1951: Rytmika dobowa aktywności gryzoni Clethrionomys glareolus Schreber i Sylvimus flavicollis flavicollis Melchior i jej zależności od od warunków świetlnych. Rozpr. Wydz. Mat.-przyr. PAN, 74B: 151-187.

16. Kulicke H., 1962: Aktionsraum und Revier'halten bei Erdmaus (Microtus agrestis L.) und Röthelmaus (Clethrionomys glareolus Schreb.). Symp. theriol., Czechosl. Acad. Sci.: 195-201. Praha.

17. Kuznetsov G. V., 1968: Periody sutočnoj aktivnosti lesnych myšej i kustarnikovych polevok. Tezisy dokladov molodežnoj naučnoj konferencii IÈMĚz AN SSSR: $47-56$.

18. Mazurkiewicz M., 1983: Spatial organization of the population. [In: "Ecology of the bank vole", Ed. K. Petrusewicz]. Acta theriol., 28, Suppl. 1: 117-127.

19. Miller R. S., 1955: Activity rhythms in the wood mouse, Apodemus sylvaticus, and bank vole, Clethrionomys glareolus. Proc. zool. Soc. Lond., 125: 505-519.

20. Obrtel R. \& Holišová V., 1974: Trophic niches of Apodemus flavicollis and Clethrionomys glareolus in a lowland forest. Acta So. Nat. Brno, 8: 1-37. 
21. Ostermann K., 1956: Zur Aktivität heimischer Muriden und Gliriden. Zool. Jb. Physiol., 66: 355-388.

22. Petrusewicz K., Górecki A., Grodziński W. \& Kozłowski J., 1983: Productivity and energetics. [In: "Ecology of the bank vole", Ed. K. Petrusewicz]. Acta theriol., 28, Suppl. 1: 173-205.

24. Saint Girons M. Ch., 1960: Le rhythme nycthéméral d'activité du campagnol roux, Clethrionomys glareolus (Schreber, 1780). I. Les males. Mammalia, 24: $516-532$.

25. Saint Girons M. Ch., 1961: Le rhythme nycthéméral d'activité du campagnol roux, Clethrionomys glareolus (Schreber, 1780). II. Les females. Mammalia, 25: $342-357$.

26. Sokolov V. E. \& Kuznetsov G. V., 1978: Sutočnye ritmy aktivnosti mlekopitajuščich. Nauka: 1-263. Moskva.

27. Tumanov I. L., 1969: Interspecific differences in indices of mator activity of Muriade rodents. Vest. Zool., 2: 15-19. [In Russian].

28. Vickery W. L. \& Bider J. R., 1981: The influence of weather on rodent activity. J. Mammal., 62: 140-145.

Accepted, February 18, 1985

\section{J. M. WOJCIK i K. WOEK}

\section{AKTYWNOSC DOBOWA DWU KONKURUJĄCYCH GATUNKOW GRYZONI: CLETHRIONOMYS GLAREOLUS I APODEMUS FLAVICOLLIS}

Metodą wielokrotnych złowień (CMR) w pułapki żywołowne (stożki i zapadkowe) badano aktywność dobową nornicy rudej (C. g.) i myszy leśnej wielkookiej (A. f.) na terenie Białowieskiego Parku Narodowego w latach 1967-1968.

$\mathrm{Na}$ wiosnę C. g. odznaczała się wielofazowym wzorcem aktywności dobowej z głównym maksimum w godzinach rannych (Ryc. 3A i 4). W 1967 r. zaznaczyły się istotne różnice w aktywności samców i samic C. g. o godz. 8, 12 i 16 . Następnej wiosny takich różnic nie stwierdzono (Ryc. 5A). Latem C. g. charakteryzowała się zmiennym wieloszczytowym wzorcem aktywności dobowej (Ryc. 3C, D). Wystąpiły wyraźne różnice w aktywności C. $g$. w dwu kolejnych sezonach letnich (Ryc. 4). Przy dużym zagęszczeniu osobników obu gatunków (lato 1967), w czasie największej aktywności $A$. f. nastąpiło wyraźne obniżenie aktywności $C$. $g$. Natomiast $w$ pozostałych okresach badań tego zjawiska nie obserwowano. Wówczas to również stwierdzono, że dorosłe samce C. $g$. wykazywały bardziej wyrównana aktywność w ciagu doby niż młode samce, a w przypadku samic stwierdzono zależność odwrotną (Ryc. 6A). Przy mniejszych zagęszczeniach gryzoni (lato 1968) wzorzec aktywności dobowej C. g., podobnie jak wiosna, był trzyszczytowy z głównym maksimum o północy. Poza tym aktywność nie była istotnie zależna od wieku zwierząt (Ryc. 6A). Jesienią u C. g. zaznaczyło się rozległe maksimum aktywności w godzinach nocnych (Ryc. 3E). W ciagu dnia osobniki tego gatunku łowiły się nielicznie. Nie stwierdzono w tym czasie istotnych różnic w aktywności samców i samic C. $g$. (Ryc. 5C).

Wzorce aktywności dobowej $A$. $f$. we wszystkich sezonach były jednoszczytowe, typowo nocne, $\mathrm{z}$ maksimum $\mathrm{w}$ godzinach od 22 do 2 i nie różnily się istotnie (Ryc. 5A-C). Jedynie latem 1967 roku stare samce w nocy były bardziej aktywne niż młode, a w dzień stwierdzono zależność odwrotną (Ryc. 6B). 